\title{
Helping One's Neighbor: Teaching and Learning Prosocial Behavior in a Religious Community
}

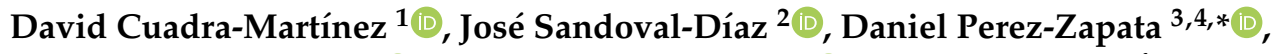 \\ Pablo Castro-Carrasco ${ }^{5}{ }^{(\mathbb{D}}$, Douglas Véliz-Vergara ${ }^{6}{ }^{\circledR}$, Javiera Guzman-Ávalos ${ }^{6}$ and \\ Gabriel Ramos-Thompson ${ }^{6}$ \\ 1 Departament of Psychology, University of Atacama, Copiapó, Copayapu 485, Chile \\ 2 Departament of Psychology, Univerity of Bio Bio. Study Center Nuble and Gender, Citizenship, and Equity \\ Research Group, GECIEQ (DIUBB GI 152124/EF), Avda. Andrés Bello 720, 3800708, Chile \\ 3 School of Psychology, University of Birmingham, Birmingham B15 2TT, UK \\ 4 School of Psychology and Philosophy, University of Tarapacá, Arica, 18 de Septiembre 2222, Chile \\ 5 Departament of Psychology, University of La Serena, La Serena, Matta 147, Chile \\ 6 Departament of Psychology, University of Atacama, Copiapó, Copayapu 485, Chile \\ * Correspondence: daniel.perez.zapata@gmail.com
}

Received: 9 May 2019; Accepted: 18 August 2019; Published: 5 September 2019

\begin{abstract}
The aim of this study was to describe and interpret the subjective theories that support the development, teaching, and learning of prosocial behavior in a Pentecostal Methodist church located in the Atacama Region (Chile). The study was descriptive-interpretative, with qualitative methodology and a case study design. We worked with 140 church members, employing qualitative observation, episodic interviews, and discussion groups. The data were analyzed using 2 techniques: thematic coding and grounded theory. Results make it possible to describe (a) the context where prosociality is developed, taught, and learned, (b) the subjective meaning of helping behaviors, and (c) community members' subjective theories about the development of teaching-learning. In the discussion, results are analyzed considering the available scientific evidence and the limitations of the present study. Also, new questions are presented which future research may explore to generate a formal theory about the development, teaching, and learning of prosocial behavior in community contexts.
\end{abstract}

Keywords: prosocial behavior; development; teaching; and learning; Pentecostal Methodist church; subjective theories

\section{Introduction}

Nowadays, one of humanity's main challenges is to learn to live in peace and harmony with our social surroundings and environment. More than ever before, science must try to understand how to encourage the development of social groups characterized by solidarity and prosociality. The present study aims to contribute to this goal through the study of the development, teaching, and learning of prosocial behavior in a social group that frequently displays helping behaviors: A Protestant Christianity community (Kraft 2016).

Prosociality has been defined as a positive, voluntary, and altruistic behavior whose main characteristic is the delivery of help or a benefit to one or more people (Dunfiel and Kuhlmeier 2013; Eisenberg et al. 2010). Some studies have linked it to neuropsychological correlates (Moya-Albiol et al. 2010), positive emotions like joy and happiness (Coma and Carbonell 2015), negative emotions when dealing with death (Hirschberger et al. 2008), or emergent reactions to catastrophes (Alvarado et al. 2016). 
Other researchers have reported associations with personality components such as goodness and altruism (Warneken et al. 2011) or personal achievements and satisfaction (Einolf 2010).

In general, two theoretical positions exist: one that regards cognitive-motivational conditions as the core of this behavior, with altruism at the center of the concept (Hepach et al. 2016), and another that emphasizes the behavioral manifestation of prosociality (Auné et al. 2014) regardless of the intention behind it.

(Hay and Cook 2007) associate this behavior with (a) emotions and feelings toward others such as friendship, empathy, and affection; (b) cooperating with and working for others; and (c) serving others considering their needs. In this process, authors identify situational factors that make it easier to provide help, while also facilitating planning and strengthening the underlying motivations of prosocial behavior (Dunfiel and Kuhlmeier 2013).

Regarding the origin of prosociality in human life, authors assume the existence of a complex setting that comprises multiple interrelated factors of a biological, personality, family, and sociocultural nature (Garaigordobil 2014). With respect to the latter factor, as children develop, it is believed that socialization teaches them to be selective in their behaviors toward others, thus orienting their help to benefit third parties (Tomasello 2010).

From an institutional-cultural perspective, religion has been shown to have positive effects on the personal development and prosociality of the faithful (Hardy et al. 2010). Nevertheless, little is known about the dynamics and mechanisms that mediate the relationship between prosociality and religion (Einolf 2011). Studies are needed which can shed light on how prosociality occurs in religious contexts.

(Heineck 2014) notes that participating in church activities has moderately positive effects on the development of prosocial behavior. Specifically, religious beliefs and support appear to have a positive association, though in-group prosociality tends to manifest itself more often (Levy and Razin 2012). However, some authors have asserted that attending church is no guarantee of prosocial behavior; instead, they note that spiritual experiences (Einolf 2013; Musick and Wilson 2008), religious identity (González and Lay 2012), a feeling of transcendence, and belief in a personal relationship with God (Schlehofer et al. 2008) are necessary.

(González and Lay 2012) explain that religious identity is mediated by empathy and prosociality, which appears to be linked to the donation of money and time. Helping one's neighbor is an element that tends to be common across religions. As a value, it establishes norms and procedures for aiding others (Furrow et al. 2004), with social networks being relevant in the promotion of prosociality (Musick and Wilson 2008). (McIntosh et al. 2005) note that being part of a religion entails a feeling of unity and responsibility for others, as well as a tendency to search for the common good.

Regarding Protestant Christianity ${ }^{1}$, (Einolf 2011) asserts that religious values, ideas, and the language present in this context motivate prosocial behaviors. According to (Stoll 1990), Protestant Christianity has three core characteristics: (a) the authority and infallibility of the Bible, (b) salvation through an intimate relationship with Jesus Christ, experienced as rebirth, and (c) commitment to helping spread the message of salvation. Indeed, the Protestant Christian tradition, through the preaching and dissemination of its faith, seeks to induce individuals to convert.

Although studies on prosociality in Protestant Christian churches are scarce, research suggests that these communities help others guided by the notion of human dignity, with spiritual aid being valued above material aspects (Kraft 2016). Also, when socio-natural disasters strike, they are the first to respond and the help that they provide tends to be efficient (Nkwachukwu 2011). Community members participate in various contexts of everyday life (Mansilla and Muñoz 2017), displaying a strong community spirit, also known as social evangelism (Reyes and Rodríguez 2014), and delivering

1 In Latin America, unlike Catholics, Protestants lack an unified church and are instead divided into various denominations or churches. 
material and spiritual help to the incarcerated, the sick (Marín 2016), the poor, and the needy, to name but a few.

In this context, we can formulate several questions from a social perspective of prosociality in religious institutional settings: how is the development and teaching of prosociality organized in these religious communities?, how does prosociality develop?, how do community members learn to be prosocial?, what pedagogical resources foster the acquisition of this behavior?, and how can we characterize the prosocial behavior encouraged by this religious community? It is interesting to find answers to these questions based on subjective or quotidian knowledge, from the point of view of subjective theories (STs), since they are more developed subjective argumentative representations (Flick 2017) that reflect the knowledge constructed by people based on their experience. STs are understood as complex cognitions that, as a hypothesis, are useful for people to explain (Klepser et al. 2017), justify, and make sense of individual experiences, their environment, and key aspects of themselves (Groeben and Scheele 2000). An especially critical function of STs is that they guide people's actions, that is, they are neither abstract beliefs nor isolated meanings of the context; instead, they are situated hypotheses that lead subjects' behaviors. Considering the latter element, we hold that studying STs about prosociality can help us understand the personal belief systems of individuals, which might articulate their cognitive-motivational aspects with their overt behaviors. This theoretical operation allows us to keep our distance from the internalist or situationist extremes that characterize the two main approaches to prosociality.

Thus, the following research problem was delineated: How do the members of a Pentecostal Methodist church located in the Atacama region of Chile theorize about the development, teaching, and learning of prosocial behavior? Our general aim was to describe and interpret these STs in order to contribute to the scientific understanding of prosociality from a social perspective. The specific aims defined were: (a) to describe the context where prosociality and its supporting STs develop and are taught; (b) to describe the way in which the participants explain the teaching, development, and learning of prosociality in this context; (c) to characterize the prosocial behavior of this religious community, considering its STs and conducting a second-order interpretation; and (d) to propose a comprehensive model of the development, teaching, and learning of prosocial behavior grounded on the STs found.

The pertinence and relevance of this study rest on the need to achieve a better scientific understanding of prosocial behavior (Dunfiel and Kuhlmeier 2013), especially regarding the way in which it is developed, taught, and learned, given that it has a major positive impact on personal and social quality of life (Arias 2015; Coma and Carbonell 2015). This topic will be examined in a religious context, given the helping behaviors present in these settings (Nkwachukwu 2011) and the limited research conducted on the relationship between religion, prosociality, and subjectivity (Einolf 2011).

\section{Method}

\section{Type of Study, Methodology, and Design}

A descriptive-interpretative study was conducted using a qualitative methodology in order to understand the problem from the perspective of quotidian or subjective knowledge (Flick 2017). A case study design was adopted (Yazan 2015) to generate an in-depth and detailed description of the phenomenon in a specific case, which facilitated our understanding of the problem. In this study, we examine the Pentecostal Methodist Church of Chile (PMCC), which is part of transnational organization whose doctrine is Pentecostal Methodis.

This is a branch of Protestantism that highlights the direct action of the Holy Spirit on their members. In Latin America, this church is characterized by: (1) a salvation message, which is grounded in the belief in a second coming of Christ; (2) a religious symbology that regards God as a miraculous, transformative, and holy spiritual force; and (3) an emphasis on the community connections of the Pentecostal cult. The Chilean branch of this church exists within the context of a 
"Criollo Pentecostalism", which is characterized by its strong roots in popular culture and a close link with the political ideas of the Chilean nation.

\section{Participants}

The participants are members of a Pentecostal Methodist church located in a municipality of the Atacama region (Chile). Nowadays, the PMCC is organised in "transnational networks" that are present in Central America, South America, the USA, Australia, Africa, Spain, France, and Sweden (Iglesia Metodista Pentecostal de Chile IMPCH; Fediakova 2002). This church has existed for 25 years and currently has 140 members, most of whom took an active participation in the building of the temple. In general, they are from a low-SES background and live in a neighborhood marked by high social vulnerability. The weekly operation of the church includes religious services, a Sunday school where Protestant Christianity is systematically taught, and meetings in which these activities are planned. This community is composed of 4 groups: (a) the child group, made up of 30 children aged 11 and under; (b) the youth group, made up of 20 single young people between 12 and 25 years of age; (c) the volunteer group, made up of 40 men who are married and/or are fathers, and (d) the Dorcas group, made up of 50 women who are married and/or are mothers. A theoretical sampling strategy was adopted (Flick 2017) which considered the following inclusion criteria: (a) participating in church activities at least once a week and (b) having been part of the church for at least one year. ${ }^{2}$

\section{Information Collection Procedure}

Access to the field was gained through the church pastor, who was informed of the aims of the study. Afterward, during a meeting, church members received information about the study and the ethical criteria adopted. In addition, the ethical criteria of the study were presented. The process began with qualitative observations of Sunday school and religious services. The analysis of the data collected guided the subsequent information collection stage. Then, interviews were held, followed by discussion groups. The latter instrument made it possible to contrast and expand the preliminary results in a group work context that facilitated the elicitation of collective STs (Catalán 2016). This sequence of information collection techniques made it possible to gradually develop a comprehensive theory of the phenomenon studied in interaction with the data. Multiple participants, observation settings, and instruments enabled us to reach theoretical saturation and gave credibility to the study via the use of intra-method triangulation. The instruments employed are detailed below:

Observation. Observations were conducted with a minimum level of participation, adopting the approach that (Flick 2017) labels observer as participant. We sought to observe church members in daily interactions, in the context of religious service and Sunday school, in order to capture what (Ammerman 2014) defines as "popular religion, which is usually taken to mean the religion of the ordinary people" (p. 190), considering the religious dimensions of everyday life.

These observations comprised the following phases (Flick 2017): (a) selection of the environment to be observed, the first of which was Sunday school, followed by the Sunday religious service; (b) definition of the object of observation, in this case the context of the teaching of prosociality and its supporting STs, conveyed through the participants' language; (c) descriptive observations, which made it possible to characterize the context where prosociality was taught and learned; (d) focalized observations, aimed at yielding more detail about aspects found to be ambiguous, contradictory, or especially relevant to our understanding of the research problem; (e) saturation of the data collected through observation. Eight observations were conducted during Sunday school and 8 during religious services over a 4-month period. Data were recorded as field notes.

Episodic interview. This procedure makes it possible to rebuild semantic knowledge from experiential narrative knowledge. Episodic interviews are based on the assumption that episodic 
knowledge is organized closer to subjective experiences, while semantic knowledge is systematized as abstract relationships which are derived from these episodes and then generalized. Thus, these interviews are expected to provide a clearer picture of subjects' STs, since their narratives of the episodes make it easier to theorize about phenomena. Technically speaking, episodic interviews encourage people to constantly present situational narratives, chains of situations, subjective definitions of the studied phenomena, hypothetical situations, and abstract relationships, all of which makes triangulation possible in the interview itself, yielding semantic and episodic knowledge (Flick 2017). A thematic script was used which included six areas of inquiry connected to our research questions: (a) the (subjective) meaning of prosocial behavior; (b) the types of help provided and why they are provided; (c) the context where prosociality is taught and the reasons why it works; (d) the teaching of prosociality at the church; and (e) the development and learning of prosociality at the church.

Six episodic interviews were conducted with 6 Sunday school teachers ( 3 women and 3 men) which lasted approximately $1 \mathrm{~h}$ each. We opted to interview Sunday school teachers because they have an active and leading role in the systematic teaching of Christian doctrine to church members. Their roles and experiences shed light on how prosocial behavior is taught and learned by the members of the church. The interviews were audio recorded.

Discussion group. Three discussion groups were held, bringing together church members who attend Sunday school as students. To implement them, we worked with the previously established groups: (a) 6 members of the youth group; (b) 6 members of the Dorcas group; and (c) and 6 members of the volunteer group. Like the episodic interviews, this instrument explored biographical episodes (Cuadra 2016) and followed the same thematic script. The discussion groups were held at the church, lasted approximately $1 \mathrm{~h}$ each, and were audio recorded. Table 1 contains all the details of the collection instruments.

Table 1. Administration of the information collection instruments.

\begin{tabular}{|c|c|c|}
\hline Technique & Participants & Information Collection Stage \\
\hline Qualitative observation & 140 church members & First stage: 4 months of observation \\
\hline Episodic interviews & $\begin{array}{c}3 \text { men and } 3 \text { women who participate as } \\
\text { Sunday school teachers }\end{array}$ & $\begin{array}{l}\text { Second stage: } 1 \text { month of instrument } \\
\text { administration }\end{array}$ \\
\hline Discussion groups & $\begin{array}{l}18 \text { church members who attend Sunday } \\
\text { school as students }\end{array}$ & $\begin{array}{c}\text { Third stage: } 2 \text { months of instrument } \\
\text { administration }\end{array}$ \\
\hline
\end{tabular}

\section{Data Analysis Procedure}

Data analysis consisted in a combination of grounded theory techniques (Corbin and Strauss 2008) and a brief case description generated with thematic coding (Flick 2017). We used ATLAS.ti, a computer program for qualitative analysis. Thematic coding is an analysis technique derived from grounded theory that makes it possible to analyze data based on cases from which data are obtained (Flick 2017). First, a within-case analysis is carried out, which consists of representing the case according to a motto. This serves as a short identification and summary of the data for the case. Second, within-case analyses are compared to build a common thematic axis. This axis is developed by merging the open, axial, and selective coding procedures of grounded theory. This process makes it possible to triangulate methods, which gives more credibility to the data analysis and results. We describe how we performed these analysis procedures below.

Open coding was used to generate field notes, aiming to describe the context of prosociality development, teaching, and learning. Afterward, for interviews and discussion groups, intra-case analysis was conducted using codes (open coding). STs were identified, which involved reconstructing a hypothesis or theory by detecting a precedent and a consequence, in most cases using the structure if ... then (Catalán 2016). This led to the identification of verbatim phrases or paragraphs that resulted in codes expressed by the researchers as STs. Interviews and discussion groups were each identified with a case motto, which is the procedure proposed by Flick (2017) for brief case descriptions used in 
thematic coding and which consists in identifying a (verbatim or non-verbatim) phrase that represents the meanings of each case regarding the topic.

During the second stage, the researchers, in joint work sessions, grouped the cases in order to perform an inter-case analysis based on the results from the previous phase (STs and case mottoes). The following task was to clean up and differentiate the categories or topics from the open coding (Flick 2017), including the analysis of field notes, which made it possible to determine the dimensions and contents of the most relevant categories of the problem studied (Flick 2017). Relationships between categories and subcategories were also established (Corbin and Strauss 2008). The aim of this type of data coding (axial coding) was to identify supraordinate STs (STs that subordinate others) to arrange into categories the subordinate STs reconstructed through open coding, while also establishing connections between them.

During the third stage, the researchers identified a central category (selective coding) around which they connected the categories reconstructed through axial coding. This stage involved a more interpretative process, in which the researchers reconstructed a supraordinate STs that explain the phenomenon studied through a model; also, a brief passage and a concept map are presented to describe and illustrate the theory generated (Flick 2017).

\section{Results}

A summary of the intra-case analyses performed is presented in Table 2. Each case is described using its motto and the STs about prosocial behavior that represents it.

Table 2. Intra-case analyses.

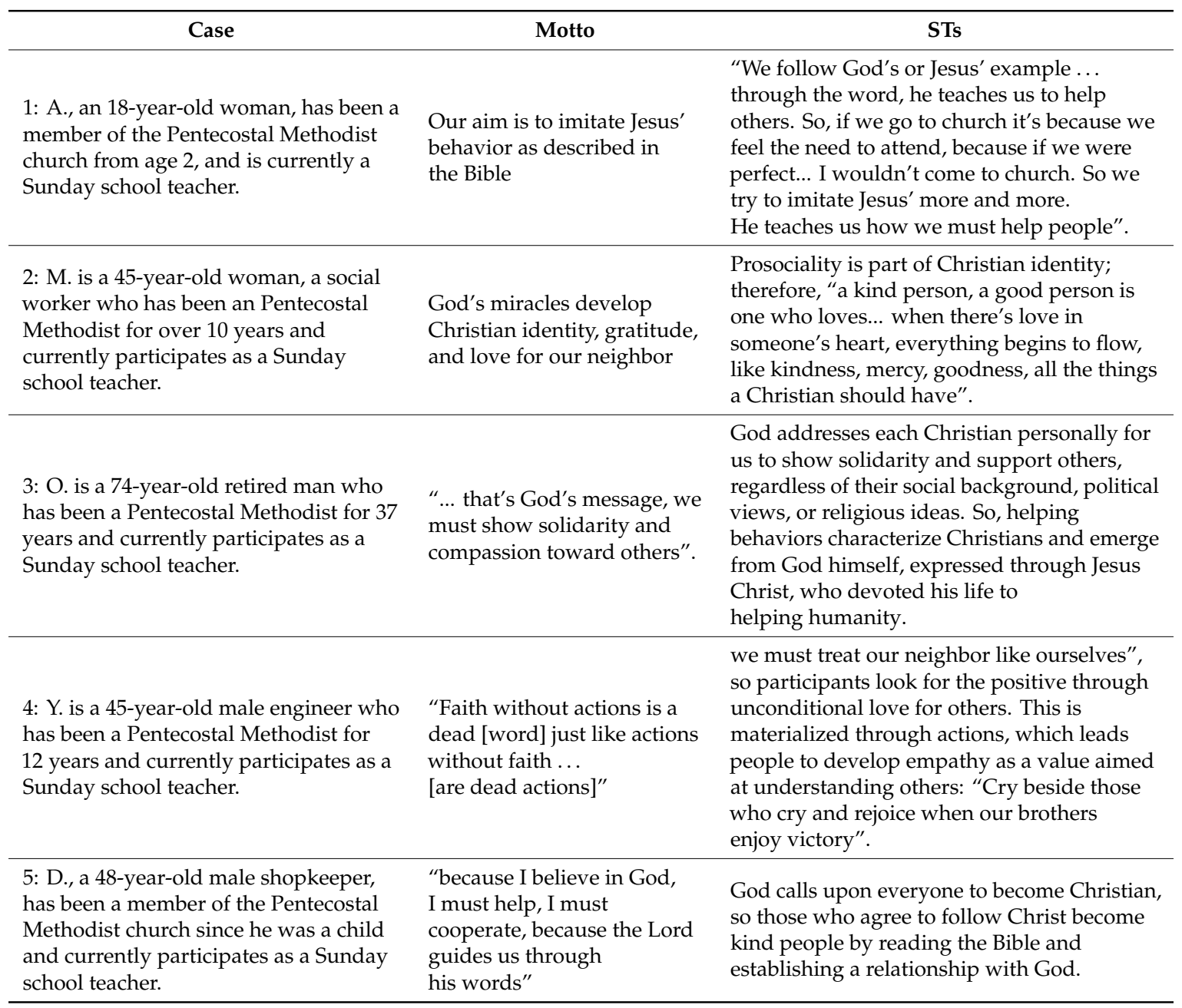


Table 2. Cont.

\begin{tabular}{|c|c|c|}
\hline Case & Motto & STs \\
\hline 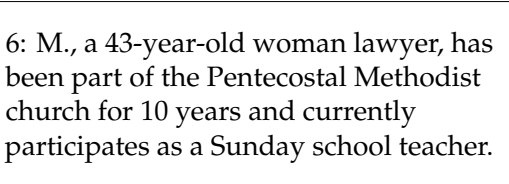 & $\begin{array}{l}\text { "You know people by their } \\
\text { fruits, and what are their } \\
\text { fruits? their attitudes" }\end{array}$ & $\begin{array}{l}\text { "Kindness is a fruit of the spirit, therefore, } \\
\text { it must be a quality of human beings, and } \\
\text { these include kindness, temperance, } \\
\text { self-control, fear of God... so kindness is one } \\
\text { among many fruits" }\end{array}$ \\
\hline $\begin{array}{l}\text { 7: a group of } 6 \text { young people aged } \\
\text { 14-25. Most of them are in the church } \\
\text { choir. They have had a variety of } \\
\text { trajectories within the church. }\end{array}$ & $\begin{array}{l}\text { "... God's love is like this, } \\
\text { loving our neighbor like } \\
\text { ourselves and that's what we } \\
\text { try to do ..." }\end{array}$ & $\begin{array}{l}\text { (Participant 3): “... we try to imitate Jesus, } \\
\text { that's our goal, to imitate him, [because] he } \\
\text { died for us and he mostly teaches us about... } \\
\text { (Participant } 4 \text { ): ... how to help our neighbor." }\end{array}$ \\
\hline $\begin{array}{l}\text { 8: a group of } 6 \text { adult men, part of the } \\
\text { church's volunteer group, who vary in } \\
\text { terms of age and years as } \\
\text { community members. }\end{array}$ & $\begin{array}{l}\text { "We educate people so they } \\
\text { will not lead a bad life, that } \\
\text { way we work toward } \\
\text { helping our neighbor" }\end{array}$ & $\begin{array}{l}\text { Human conflict is within us (p1), we have lost } \\
\text { our values (p2), so we will encounter } \\
\text { problems as long as we do not solve this. } \\
\text { [so] help goes beyond material things, it is } \\
\text { necessary to teach, that's the best way of } \\
\text { helping, so other people can learn the right } \\
\text { way (p3). }\end{array}$ \\
\hline $\begin{array}{l}\text { 9: a group of } 6 \text { adult women who are } \\
\text { mothers or are married, aged } 18 \text { and up } \\
\text { (with some being older adults). They } \\
\text { differ in terms of how long they have } \\
\text { been church members. }\end{array}$ & $\begin{array}{l}\text { "for us, as people, doing this } \\
\text { [helping] springs from } \\
\text { our heart" }\end{array}$ & $\begin{array}{l}\text { (Participant 2) "If you're on the street... it } \\
\text { can be money or some kind words ... you } \\
\text { reach that person, and that person says: oh!, } \\
\text { that's exactly what I wanted to hear, so it's not } \\
\text { only something that's taught, it's something } \\
\text { within you" ... "(Participant } 1 \text { ) that's what } \\
\text { God has taught us, that we need to share } \\
\text { what's ours with those who suffer ... so I say } \\
\text { we do all this just out of love and affection" }\end{array}$ \\
\hline
\end{tabular}

Source: own work. Note: some mottoes and STs are verbatim quotations; in other cases, the researchers reconstructed the motto and the STs to make them more easily understandable.

The comparative analysis of all cases, along with the field notes collected, made it possible to generate a shared set of themes which were described using open coding.

\section{The Context of Prosociality Development, Teaching, and Learning}

This community displays structural traits which facilitate the development, teaching, and learning of prosociality. We define these features as organizational, physical, social, and practical dimensions of the church. Table 3 summarizes prosocial activities at the Pentecostal Methodist church.

The church's identity is symbolically grounded in the notion of the trinity, according to which three distinct entities exist in God: the Father, the Holy Spirit, and Jesus Christ. The church is aimed at disseminating the Bible's message for people's salvation, one of whose core values is solidarity and helping others. This perspective is reflected in its goals of preaching the gospel according to Jesus Christ's teachings, providing help for the needy, and taking part in cultural, social, and spiritual initiatives that benefit the community.

From a physical point of view, the church is arranged in a way that facilitates and encourages meetings and communication among its members, along with alterity elements, greetings, and messages of hope and salvation. The church frequently organizes events such as breakfasts, lunches, and Christian encounters, all of which can be hosted thanks to its facilities, which are spacious and fit for purpose.

Field note 4: It is a two-story building. There are halls for holding religious services on the ground floor and first floor; there is a bathroom and a kitchen. It is decorated with messages of good tidings, hope, and salvation.

From a social point of view, interactions between members involve prosocial dynamics characterized by: (a) a desire to foster other people's development, manifested through blessings and good wishes, support, and guidance for dealing with issues. (b) An inclusive relationship, which involves an explicit invitation to be part of the group. (c) Empathy and affection, expressed through 
close interactions that encourage trust within the group. All this is present in case three: "Brother, God's teaching is that we should embrace everyone, regardless of their social background, no matter their job, home, or family..."

From a practical point of view, prosociality is expressed through spiritual help and material aid for the community in general. Spiritual help entails spiritual guidance and emotional support, along with prayer so God will embrace and aid the troubled person and/or solve the problem affecting him/her. Material aid is manifested through the donation of money, food, clothes, and medicines to those in need, regardless of whether they are church members.

Case 2: Well, the church provides two kinds of help: spiritual, which people may need to quit drugs, alcohol, to overcome problems... because sometimes people come here and they have a big problem, so the help we provide is of this type: spiritual, let them come to the Lord, accept Jesus Christ... but we also give them material help.

Table 3. Prosocial activities at the Pentecostal Methodist church.

\begin{tabular}{|c|c|c|}
\hline Type of Help & Activity & Description \\
\hline \multirow{5}{*}{ Spiritual } & Prayer & $\begin{array}{l}\text { Includes requests for God to provide a solution to } \\
\text { various problems that people are dealing with. It is a } \\
\text { personal activity both inside and outside the church and } \\
\text { a collective activity scheduled as a weekly meeting. }\end{array}$ \\
\hline & Bible study & $\begin{array}{l}\text { The church's most important activity, regarded as } \\
\text { guidance to be a good Christian. }\end{array}$ \\
\hline & Invitation to join the church & $\begin{array}{l}\text { Aimed at those who visit the church and the wider } \\
\text { community. It is characterized by a kind, affectionate, } \\
\text { and inclusive relationship. }\end{array}$ \\
\hline & $\begin{array}{l}\text { Visits to hospitals, prisons, } \\
\text { church members, and neighbors }\end{array}$ & $\begin{array}{l}\text { Visits to public institutions and homes, mainly to } \\
\text { provide spiritual support }\end{array}$ \\
\hline & Weekly preaching & $\begin{array}{l}\text { Conducted at a public venue. Consists in teaching God's } \\
\text { word to the community, providing messages of salvation, } \\
\text { support, and hope. }\end{array}$ \\
\hline \multirow[b]{2}{*}{ Material } & Offerings and tithing & Voluntary monetary contributions to the church \\
\hline & Donations & $\begin{array}{l}\text { Money, food, medicines, and clothes, among other } \\
\text { resources, are given to church members and the } \\
\text { wider community. }\end{array}$ \\
\hline
\end{tabular}

Source: own work.

The development, teaching, and learning of prosociality requires four interconnected microstructural conditions: (a) an organizational dimension, composed of a prosocial philosophy and values that ground social relationships, shape physical space, and orient practices. Based on this, (b) the social dimension generates interactions involving affect, support, and trust among church members, which include systematic teachings on how to be prosocial. All this takes place in (c) a physical dimension that makes it easier for members to gather and promotes group development. This influences the (d) practical dimension, which manifests itself through helping behaviors. Probably, any institution that systematically considers these 4 dimensions will be better prepared to develop, teach, and promote the learning of prosocial behavior (see Figure 1). 


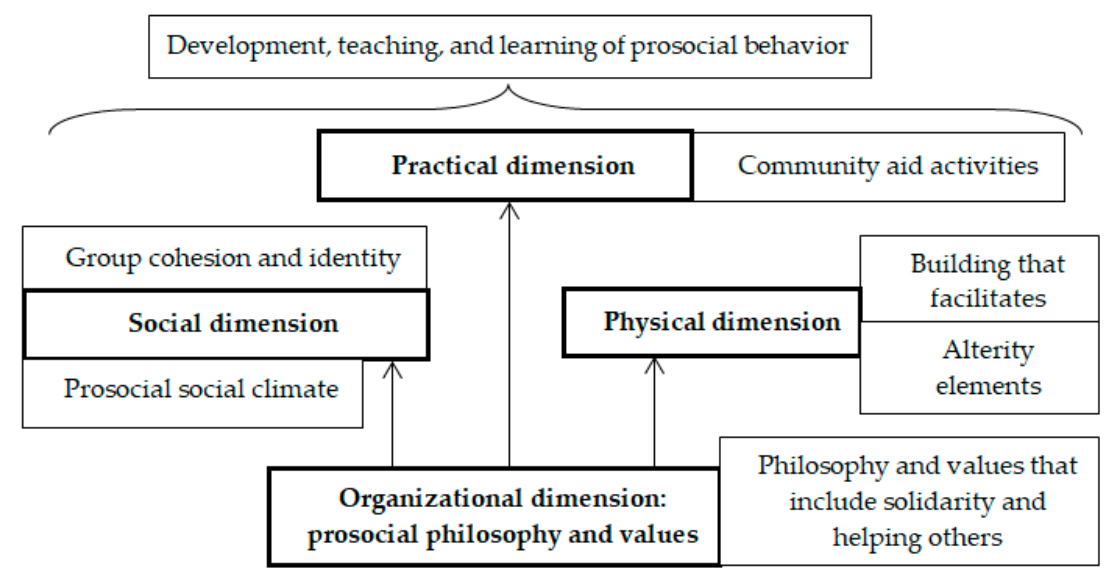

Figure 1. Axial coding: microstructural conditions of the development, teaching, and learning of prosocial behavior.

\section{Subjective Meaning of Prosociality}

The participants' STs indicate that helping behaviors are part of Protestant Christian identity. They explain that a "good Christian" is someone who treats his/her neighbor kindly. Conversion to Protestant Christianity entails separating oneself from the "sinful" life of society and finding new meaning in one's life and the world.

One's neighbor, according to Jesus' teachings, is a peer who is often weaker or needy. One's should treat one's neighbor as if he were oneself; thus, prosocial treatment is sought through unconditional love toward others: "Cry beside those who cry and rejoice when our brothers enjoy victory" (Case 4).

An ST that prescribes prosociality is observed, according to which love promotes the values of goodness, mercy, and kindness. Prosociality is regarded as a divine mandate and a way of being Christian:

Case 1: That's God's message, we must show solidarity and compassion toward others.

Case 7, participant 3: because in the end, if we all loved each other, if we were as the Bible says... this world would be perfect, like God, it would be perfect, but since we all disobey and want to do things our way, the world is the way it is now.

Prosociality can thus be regarded as a divinely mandated process that involves developing kindness as part of being a Christian. It does not only comprise prosocial values and norms: it must also be expressed through recurrent helping behaviors (see Figure 2).

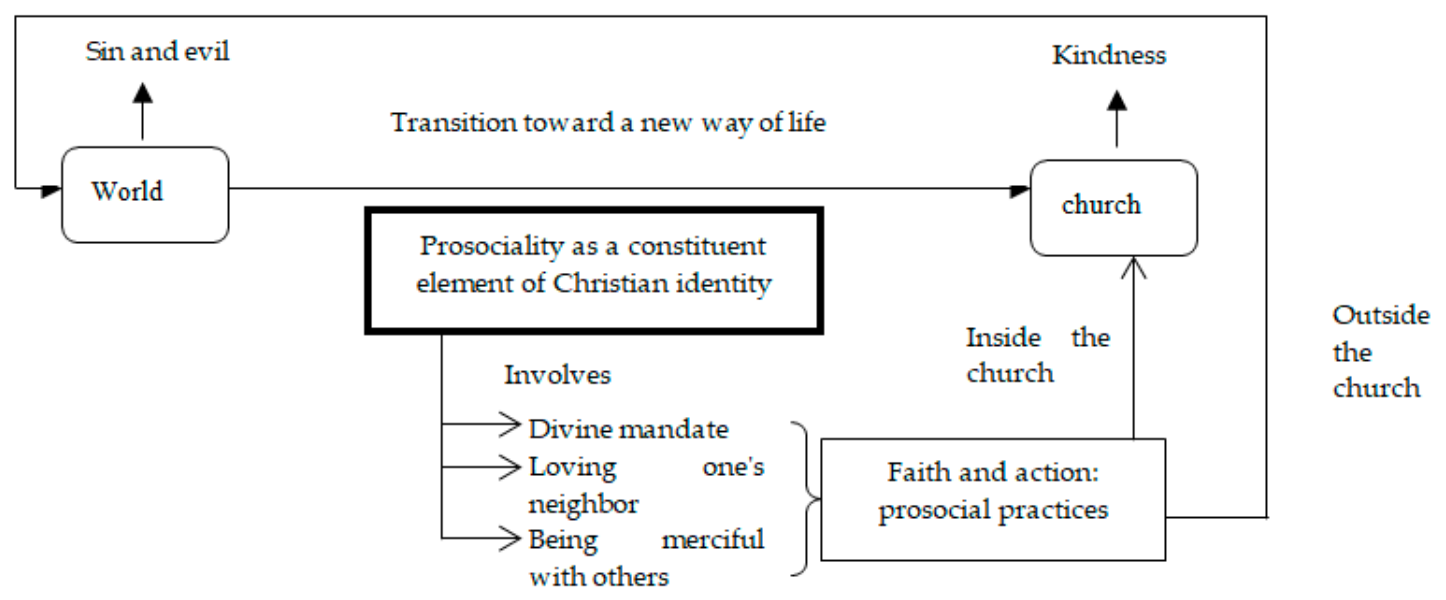

Figure 2. Axial coding: subjective meaning of prosociality. 


\section{Development, Teaching, and Learning of Prosociality}

\subsection{Development of Prosociality}

The participants display an essentialist ST about prosociality. Good is inherent to human beings, because man and woman were made in God's image and God is infinitely good; however, human beings are free to follow or reject Christian teachings while living in a society that encourages sin and separates them from their good essence. Thus, the church is regarded by this group as a context that makes it possible to rediscover this good essence. This point is made in case 2: "I think God did make all of us good, God's creation is good, but He gave man free will, I can decide, so the heart of man tends to do evil".

A second ST associated prosociality with religious conversion, which results from an existential breakdown that is solved by joining Protestant Christianity. This metamorphosis enables people to develop a religious and spiritual identity grounded on solidarity. In this process, new Christians find new meaning in their life and the world, with prosociality emerging as a relevant value of Christian identity. Religious conversion causes profound feelings of gratitude and faith to develop, which grow and feed on God's solutions to new problems in people's lives. These solutions are interpreted as miracles and "Wonders effected by God ... " (Case 1). Such events reaffirm both the participants' Protestant Christianity and the value of engaging in prosocial behaviors.

(Case 3) ...I came out of the hospital totally sick, after spending a year hospitalized. I came back home [to die] and I lay in bed... everyone thought I was going to die... They prayed there with my wife... I woke up the next morning, around 7, and I was like new. There was no heaviness in my body, no pain at all. I got up, I told.: "You know, I., the Lord cured me. I went out and there was a fig tree, I praised God, I thanked him, and that's why I'm so grateful toward him (cries).

Human beings are essentially good and enjoy free will. They can choose to seek God or walk away from Him. Contact with this religion makes it possible to develop this kind essence through socialization or conversion. In the people who convert, this occurs through a set of existential breakdowns that are overcome within the religious community. This leads to the development of faith and gratitude, which shapes a new ST about oneself and the world, one in which spirituality, kindness, and a sense of transcendence are key. As a result, the convert incorporates prosociality into his/her personal and Protestant Christian identity (see Figure 3).

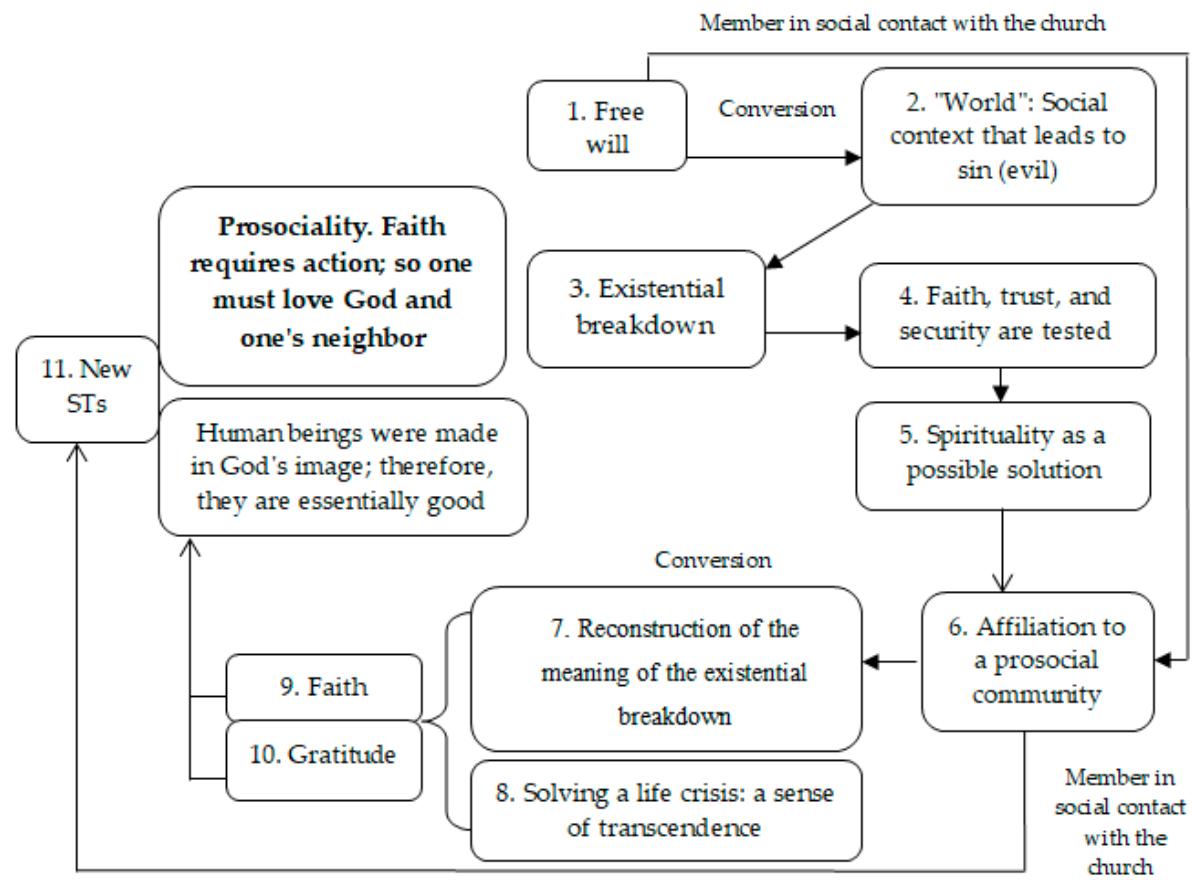

Figure 3. Axial coding: development of prosociality. 


\subsection{Teaching and Learning of Prosociality}

Three STs were found regarding the teaching and learning of prosociality. The first explains that, in order to learn kindness, it is necessary to have motivation to convert to Protestant Christianity or the need and the will to learn about it. For this group, the knowledge taught is sacred; therefore, people should not be forced to learn it, because this entails disrespecting the transcendent. "God says that he does not force man to follow His gospel, it is not obligatory, it is voluntary. So, the way we deal with this, we ask, and if they say yes, they are willing to listen, they want to learn... but if they say no, it's a no" (Case 6).

The second ST explains that teaching Christian knowledge involves learning to be prosocial. The Bible is regarded as God's word and regulates all human behavior. Its messages are studied and conveyed through prayer, written messages, hymnals, Bible teaching lessons, and religious services. Analyzing these contents often leads church members to "be good Christians", an attitude that essentially involves following the commandments, loving and praising God, and supporting one's neighbor. Some biblical contents are explicitly prosocial and are studied in Sunday school. In the following examples, the Apostle Paul represents one of the main role models of Protestant Christianity in this community. The hymn is one of the many that are frequently sung in this religious group:

Lastly, Paul declares that those who have been transformed by Christ put into practice justice and love in all aspects of social, civil, and moral justice (Guía para la Escuela Dominical [Sunday School Guide], volume 11, p. 54).

Love your neighbors, think of their souls, tell them the story of the good savior. Take care of the orphan; God is their Father and faithful savior (Pentecostal Methodist Church Hymnal, stanza from the hymn "Love Thy Neighbor").

Within the context of Sunday school, lesson planning is based on: (a) an intuitive dimension, since through revelation and prayer the person officiating as teacher commends him/herself to God to teach a good lesson; (b) an objective dimension, based on national lesson plans, which structures the biblical contents to be studied. A Sunday school teacher notes (Case 6):

... the person teaching has a great responsibility in terms of how they prepare the lesson ... so, if I have to teach a topic, and I present it to God, I tell Him: Lord, help me with this and give me your grace, your power... but if I take this lightly and just start teaching... it's an empty word that sometimes has no effect, so we can say this is a technique, asking for God's spirit to be present.

The third ST explains that learning to be a Protestant Christian is a personal transformation process; therefore, it requires systematic, organized teaching as well as divine guidance. This point is made in case 5 :

Now, why does one intervene?: because one has something to teach, it's a foundation established long ago, it has to do with the teachings that we have received, from the church, our training, regarding how ... how a person can be kind: it's just a matter of embracing the other. You can teach others to be kind and some of us have set roles: the pastor bears the highest authority, since he teaches human goodness and Protestant Christianity during religious services through divine revelation. The pastor selects teachers, church members who teach during Sunday school. These members are characterized by their appreciation of and dedication to the teaching role: they study and pray commending themselves to God to teach a good lesson. If we're going to teach at the altar, as preachers, we have to take care of ourselves for at least two days: no intercourse with our wives, a few days of harmony, fasting... all that helps you a lot regarding your connection with God.

Members acknowledge the importance of instruction for the learning of prosocial behavior, highlighting the following pedagogical tools: (a) the use of testimonies, which are publicly presented both inside and outside the church. Testimonies are biographical evidence of God's love and power, a miraculous solution to an existential crisis. Such events enable people to develop faith, gratitude, 
Protestant Christian identity, and an orientation toward kindness. (b) Reflection is another commonly used resource. It is not used to challenge the Bible, but to link the scriptures to one's biography, to other people's lives, or even to aspects of today's society. This makes it possible to insert abstract notions in real, local, and practical settings, thus imbuing them with meaning. (c) One's biography is often used to exemplify one's sacrifices, suffering, Christian devoutness, and kindness. (d) The singing of hymns is a more emotional way to represent one's gratitude, faith, and love toward God. In general, the contents of these songs reveal the singers' love of God, His mercy, and His power, apart from advising church members on how to live better. (e) Work groups to learn about kindness and Protestant Christianity are mainly established during Bible study meetings. In them, members contrast opinions, share mystical experiences, and discuss their ways of understanding the Bible and Protestant Christianity.

[How do you connect testimonies with the process of learning to be prosocial?] They are very important, because Christians, throughout their life, amass lots of testimonies... we've been through so much suffering, so many difficulties... God makes us stronger along the way and responds to us, and we believe that this powerful God will stay by our side and will strengthen our faith (case 3).

The teaching and learning of prosociality is represented via a ST that explains that this process that must be systematized, organized, and implemented in terms of three basic dimensions: (a) prosocial contents, (b) strategies for teaching prosociality, mainly grounded on testimonies, biographies, and group reflections, and (c) teachers, inspired by God, deeply involved in their task, and exemplary Christians. All this enables community members to gain an in-depth, meaningful understanding of how to be prosocial (see Figure 4).

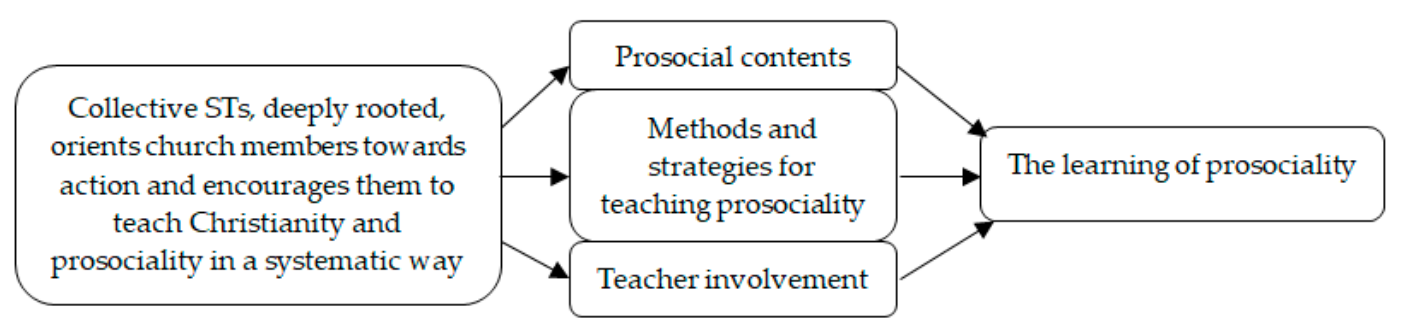

Figure 4. Axial coding: teaching and learning of prosociality.

\section{Selective Coding: Supraordinate STs about the Development, Teaching, and Learning of Prosociality}

The development, teaching, and learning of prosociality, in this Pentecostal Methodist church, is grounded on a collective STs that is deeply rooted and is strongly influenced by the community's biographical and emotional experience about the nature of human goodness and evil. In this context, in order to develop prosociality, it is necessary for the group to generate an ontological definition of a human being as someone who is essentially kind, but who can choose whether to cultivate this goodness or stray from the path to perform evil actions. When a person joins this community, either through social interaction or religious conversion, he/she finds microstructural conditions that encourage the development, teaching, and learning of prosociality, along with a systematic approach to its teaching. This enables people to develop and learn prosociality while also implementing helping behaviors that benefit church members or their neighbor in general, all of which ultimately coalesces into a ST that is part of their personal identity, where prosociality plays a key role (see Figure 5). 


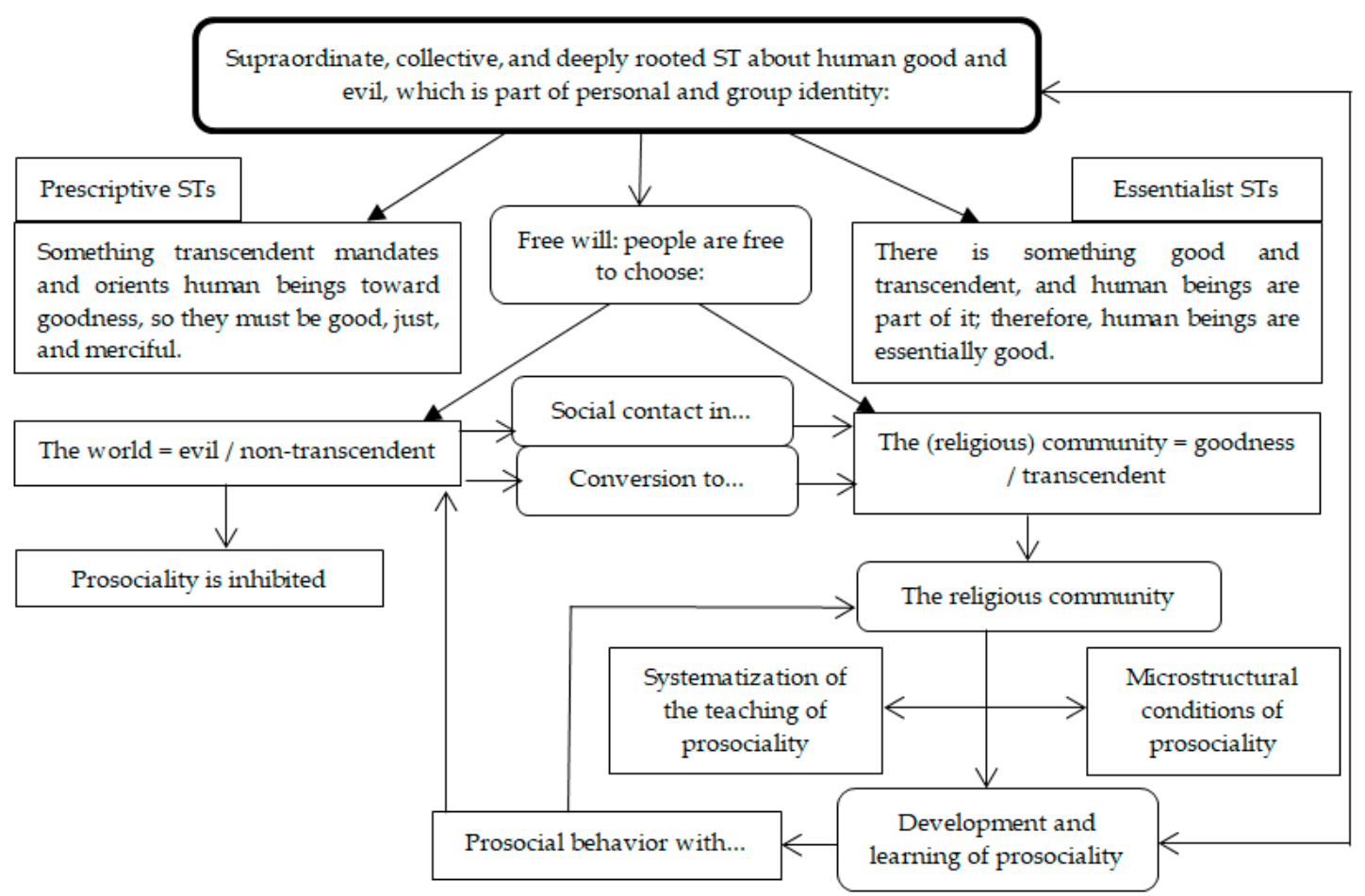

Figure 5. Selective coding: supraordinate STs about the development, teaching, and learning of prosociality.

\section{Discussion}

Globally, and especially in Latin America, it is increasingly relevant to understand how to improve coexistence. Prosocial behavior represents a promising way to achieve this goal; in fact, for (Lay and Hoppmann 2015), it is the "social glue" that enables people of different ages to live together in peace and collaboratively.

This study aimed to shed light on how people develop, teach, and learn prosocial behavior in a religious context—a Protestant Methodist church — that encourages them to acquire and elicit helping behaviors (predominantly benefiting the needy), in this case, after religious conversion. Scientific evidence shows that church participation tends to result in the development of helping behaviors among members (Einolf 2013; González and Lay 2012; Heineck 2014; Levy and Razin 2012; Schlehofer et al. 2008). However, little is known about how religious communities encourage these helping behaviors (Einolf 2011) or about how such behaviors express themselves. Understanding this could be a first step toward identifying the underlying social mechanisms of prosociality promotion in religious institutional contexts; from this starting point, it would be possible to orient processes for the teaching and learning of this behavior, which could be generalizable to other fields with similar characteristics.

The first aim of this study was to describe the context where prosocial behavior develops. The Protestant Christian religion is characterized by an identity geared toward helping one's neighbor (Einolf 2011) and adopting a humanitarian approach (Kraft 2016), all of which configures the core values that support in-group cohesion. The results obtained in this study show that, for the members of this Protestant Methodist community to develop, teach, and learn prosocial behavior, their institution requires certain structural conditions that our data analysis grouped under the organizational, physical, social, and practical dimensions.

Research on Protestant Christian communities has emphasized how their culture promotes helping behaviors among members which are based on their religious values, beliefs, and language (e.g., Einolf 2011), all of which are traits associated with the organizational dimension in our study. This dimension also includes an explicit and systematic description of institutional philosophy, according to which prosocial behavior represents a value, a goal, and an element of alterity derived 
from the Protestant Methodist church, which highlights the importance of belonging and collective identity. Other studies also show that prosocial practices are essential for these communities to increase their prosociality, highlighting the role of the spiritual and material aid that they constantly give the needy (Marín 2016; Nkwachukwu 2011). This stresses the relevance of considering a practical dimension: helping behaviors that benefit others. In this study, as part of objective 3, we presented a description of the Protestant Methodist community's systematic and habitual helping practices. These behaviors reflect the degree of participation and commitment that members display toward the church and its social evangelism (Mansilla and Muñoz 2017) by expanding the scope of their affective and material aid to the needy (Reyes and Rodríguez 2014).

The results obtained reveal the complex organization of the teaching-learning of prosociality in this religious community, where cultural, philosophical, and value-based elements related with helping one's neighbor are declared and disseminated, thus regulating the sociocultural (Musick and Wilson 2008) and physical dimensions of the group, which are aligned to establish helping behaviors that meet the conditions mentioned. However, although this enriches our understanding of the topic studied, it also poses the challenge of determining how feasible it would be for non-religious groups with teaching duties to embrace dimensions that, in Protestant Methodist contexts, promote helping behaviors and their underlying values. In line with our study, which sought to stress the relevance of quotidian knowledge, a research approach that could contribute to this goal would be to examine the prosociality development experiences of church members who also lead non-religious organizations.

The second goal of this study was to understand the development, teaching, and learning of prosocial behavior from the perspective of the participants' STs. According to the literature, prosocial behavior begins to manifest itself in early childhood based on social factors such as primary and secondary socialization processes; that is, authors consider that interaction with others fosters its development (Tomasello 2010; Waugh et al. 2015). Our findings support this view: in the religious community studied, and grounded on the microstructural conditions mentioned, a socialization process occurs which enables people to develop prosociality. A second path appears to forge a more deeply rooted personal Christian identity within a cohesive in-group framework (González and Lay 2012), in which an existential breakdown triggers a religious conversion that ultimately results in faith, gratitude, and the construction of a core ST strongly marked by biographical and emotional elements. Thus, the converted person reinterprets his/her own life and the world, embracing God's love and caring for his/her neighbor. These findings help explain why other authors have reported that prosociality is linked both to positive emotions like happiness (Coma and Carbonell 2015) and to negative emotions associated with the nearness of death (Hirschberger et al. 2008) or catastrophes (Alvarado et al. 2016).

The teaching and learning of prosociality is one of the least researched processes within the context of religious communities. By examining the participants' STs, this study aimed to identify systematic and organized processes through which members of a Protestant Methodist church acquire prosocial behaviors. Some studies have stressed the importance of norms and procedures for promoting helping behaviors (Furrow et al. 2004), the generation of social cohesion, a sense of responsibility, and the common good (McIntosh et al. 2005). Our findings reveal the complex systematization of the teaching of prosociality, rich in pedagogical strategies which ultimately help reconstruct an ST about the self and the world. Its most salient elements are the integration of several aspects aimed at producing deep, lasting, and meaningful learning, which can be classed as (a) prosocial contents, (b) exemplary teachers who are committed to their teaching duties, and (c) a pedagogical strategy that combines biography, reflection, and group work in order to achieve a deep, lasting, and meaningful subjective change (Krause et al. 2006) in terms of helping behaviors. This process is one of the critical factors enabling this Pentecostal Methodist church community to develop a Christian identity and acquire competencies to behave prosocially.

Lastly, we propose a comprehensive model of the development, teaching, and learning of prosociality within the context of a Protestant Methodist church. In our view, this is a substantial theory 
that could be validated in social contexts other than churches in order to construct a formal theory of how prosociality is developed, taught, and learned. However, it is relevant to consider the idiosyncratic elements that configure each learning environment, as well as the mediating function of the roles, norms, and institutions that regulate behavior. In addition, this model showcases the development of a collective, well-established, and strongly biographical, emotional, and symbolic ST (of a biblical nature) that could be regarded as an ontological theory about human goodness and evil. Amid this struggle between competing forces, new church members and/or the converted engage in socialization processes, benefit from structural conditions, and are targeted by systematic teaching strategies that ultimately orient prosocial behavior. These findings reveal that religious communities of this type have an effect on the development of prosocial behavior (Heineck 2014), impacting the construction of a Christian identity (González and Lay 2012) through a sense of transcendence (Schlehofer et al. 2008) focused on helping one's neighbor, under the nodal category of the needy.

Several issues emerge for future research to address. First, it would be interesting to examine the transferability of these results to other contexts, as this study only makes it possible to hypothesize that our findings apply to groups similar to the one examined (Chilean Pentecostal Methodist churches belonging to the same international network). Given that our study only examined one church, future research could include other churches in order to contrast our findings and produce more far-reaching results. This study only makes it possible to hypothesize that all the above applies to groups similar to the one studied and that are part of the same international network of Pentecostal Methodist churches in Chile. Second, it would be relevant to determine which elements limit the development of prosociality in these contexts and which conditions challenge or introduce tension to it, two aspects left unexplored in this study. Finally, some questions emerge that invite researchers to continue improving our scientific understanding of this issue, for instance, by focusing on the development and learning of this behavior from a more temporal perspective; in this regard, designs based on life histories could be a viable methodological approach.

In a contemporary social context that urgently requires a more humane approach to coexistence, a clearer understanding of prosocial behavior would make it much more feasible to generate a formal theory and would provide guidelines on how to promote and develop it outside of religious settings.

Author Contributions: Formal analysis, D.C. and J.S.; Investigation, D.P.-Z. and D.V.; Methodology, J.G. and G.R.; Writing—original draft, D.C., J.S.-D., D.P.-Z., P.C.-C., D.V.-V., J.G.-Á. and G.R.-T.; Writing—review \& editing, D.C., J.S., D.P.-Z. and P.C.-C.

Funding: This research received no external funding.

Conflicts of Interest: The authors declare no conflict of interest.

\section{References}

Alvarado, Robert, Constanza Pradenas, and Nataly Yáñez. 2016. Teorías Subjetivas y Conducta Prosocial en Catástrofes Naturales. Ph.D. Thesis, Universidad Santo Tomás, Santiago, Chile.

Ammerman, Nancy. 2014. Finding religion in everyday life. Sociology of Religion 75: 189-207. [CrossRef]

Arias, Walter. 2015. Conducta prosocial y psicología positiva. Avances en Psicología 23: 37-47.

Auné, Sofia, Diego Blum, Focundo Abal, Gabriela Lozzia, and Felix Horacio. 2014. La conducta prosocial: Estado actual de la investigación. Perspectivas en Psicología 11: 21-33.

Catalán, Jorge. 2016. Hacia la formulación de una teoría general de las teorías subjetivas. Psicoperspectivas. Individuo y Sociedad 15: 53-65. [CrossRef]

Coma, Joaquim, and Javier Carbonell. 2015. Experiencia de libre albedrío en la conducta pro-social determinada por la alegría. Escritos de Psicología 8: 41-47. [CrossRef]

Corbin, Juliet, and Anselm Strauss. 2008. Basics of Qualitative Research: Techniques and Procedures for Developing Grounded Theory, 3rd ed. Thousand Oaks: Sage Publications, Inc. [CrossRef]

Cuadra, David. 2016. Cambio representacional en los padres: Reconstrucción de teorías subjetivas de la prevención del consumo de drogas en los hijos e hijas. Estudios Pedagógicos 42: 283-98. [CrossRef] 
Dunfiel, Kristen, and Valerie Kuhlmeier. 2013. Classifying prosocial behavior: Children's responses to instrumental need, emotional distress, and material desire. Child Development 84: 1766-76. [CrossRef]

Einolf, Christopher J. 2010. Does extensivity form part of the altruistic personality? An empirical test of Oliner and Oliner's theory. Social Science Research 39: 142-51. [CrossRef]

Einolf, Christopher J. 2011. The link between religion and helping others: The role of values, ideas, and language. Sociology of Religion 72: 435-55. [CrossRef]

Einolf, Christopher J. 2013. Daily spiritual experiencies and prosocial behavior. Social Indicators Research 110: 71-87. [CrossRef]

Eisenberg, Nancy, Natalie Eggum, and Laura Di Giunta. 2010. Empaty-related responding: Associations with prosocial behavior, aggression, and intergroup relations. Social Issues and Policy Review 4: 143-180. [CrossRef]

Fediakova, Evguenia. 2002. Redes religiosas transnacionales: El pentecostalismo latinoamericano en la "era de la información". Revista de Ciencias Religiosas 11: 47-60.

Flick, Uwe. 2017. Introducing Research Methodology: A Beginners Guide to Doing a Research Project, 2nd ed. New Delhi: Sage Publishing.

Furrow, James L., Pamela Ebstyne King, and Krystal White. 2004. Religion and positive youth development: Identity, meaning, and prosocial concerns. Applied Developmental Science 8: 17-26. [CrossRef]

Garaigordobil, Maite. 2014. Conducta prosocial: el papel de la cultura, la familia, la escuela y la personalidad. Revista Mexicana de Investigación en Psicología 6: 146-57.

González, Roberto, and Siugmin Lay. 2012. Identidad Nacional, Religiosa, Valores Altruistas y Conductas de Ayuda. Seminario Solidaridad y Participación Ciudadana. Santiago: Pontificia Universidad Católica de Chile, MIDE UC.

Groeben, Norbet, and Brigitte Scheele. 2000. Dialogue-hermeneutic method and the «research program subjective theories». Forum Qualitative Sozialforschung/Forum Qualitative Social Research 1. [CrossRef]

Hardy, Sam, Michael Pratt, Mark Pancer, Joseph Olsen, and Heather Lawford. 2010. Community an religious involvement as contexts of identity change across late adolescence and emerging adulthood. International Journal of Behavioral Development 35: 125-35. [CrossRef]

Hay, Dale F., and Kaye V. Cook. 2007. The transformation of prosocial behavior from infancy to childhood. Edited by Celia A. Brownell and Claire B. Kopp. In Socioemotional Development in the Toddler Years: Transitions $\mathcal{E}$ Transformations. New York: Guilford, pp. 100-31.

Heineck, Guido. 2014. Love thy neighbor: Religion and prosocial behavior. Berg Working Discussion Paper Series 93: 1-18.

Hepach, Robert, Amrisha Vaish, Tobias Grossmann, and Michael Tomasello. 2016. Young children want to see others get the help they need. Child Development 87: 1703-14. [CrossRef]

Hirschberger, Gilad, Tsachi Eindor, and Shaul Almakias. 2008. The Self-Protective Altruist: Terror Management and the Ambivalent Nature of Prosocial Behavior. Personality and Social Psychology Bulletin 34: 666-78. [CrossRef]

Iglesia Metodista Pentecostal de Chile (IMPCH). 2015. (1 de enero de 2015). La iglesia metodista pentecostal en el mundo. Available online: https://www.impch.cl/la-iglesia-metodista-pentecostal-en-el-mundo (accessed on 12 February 2019).

Klepser, Roswitha, Holger Weitzel, and Anne-Rose Barth. 2017. The Structure-formation technique as a tool for exploring, analyzing, and promoting students' conceptions about scientific inquiry. In Qualitative Approaches to Actual Problems in Education. Edited by Günter Huber. Tübingen: Center for Qualitative Psychology, pp. 59-89.

Kraft, Kathryn. 2016. Faith and impartiality in humanitarian response: Lessons from Lebanese evangelical churches providing food aid. International Review of the Red Cross 97: 395-421. [CrossRef]

Krause, Mariane, Guillermo de la Parra, Roberto Arístegui, Paula Dagnino, Alemka Tomicic, Nelson Valdés, Oriana Vilches, Orietta Echávarri, Perla Ben-Dov, Lucía Reyes, and et al. 2006. Indicadores genéricos de cambio en el proceso psicoterapéutico. Revista Latinoamericana de Psicología 38: 299-325.

Lay, Jennifer, and Christiane Hoppmann. 2015. Altruism and prosocial behavior. Encyclopedia of Geropsychology, 1-9. [CrossRef]

Levy, Gilat, and Ronny Razin. 2012. Religious beliefs, religious participation, and cooperation. American Economic Journal: Microeconomics 4: 121-51. [CrossRef]

Mansilla, Miguel, and Wilson Muñoz. 2017. La dramatización de la cultura. Los proceso de conversión evangélica Aymara (Chile). Cungará, Revista de Antropología Chilena 49: 241-50. [CrossRef] 
Marín, Nelson. 2016. Evangelismo carcelario en Chile: Análisis socioantropológico de comunidades religiosas en contextos de encierro. Polis, Revista Latinoamericana 15: 557-80.

McIntosh, Hugh, Edward Metz, and James Youniss. 2005. Community service and identity formation in adolescents. In Organized Activities as Contexts of Development. Edited by Joseph Mahoney, Reed Larson and Jacquelynne Eccles. Mahwah: Lawrence Erlbaum Associates, pp. 331-51.

Moya-Albiol, Luis, Neus Herrero, and Consuelo Bernal. 2010. Bases neuronales de la empatía. Revista de Neurología 50: 89-100. [CrossRef]

Musick, Marc A., and John Wilson. 2008. Volunteering: A Social Profile. Indianapolis: Indiana University Press.

Nkwachukwu, Orji. 2011. Faith-Based Aid to People Affected by Conflict in Jos, Nigeria: An Analysis of the Role of Christian and Muslim Organizations. Journal of Refugee Studies 24: 473-92. [CrossRef]

Reyes, Sonia, and Juan Carlos Rodríguez. 2014. El capital religioso evangélico en la cultura lotina. Gestão e Desenvolvimento, Novo Hamburgo 11: 24-43.

Salas, Natalia. 2015. Género y Liderazgo Religioso en Mujeres Evangélicas Chilenas. Master's Thesis, Universidad de Chile, Santiago, Chile.

Schlehofer, Michèle, Allen Omoto, and Janice Adelman. 2008. How do "religion" and "spirituality" differ? Lay definitions among older adults. Journal for the Scientific Study of Religion 47: 411-25. [CrossRef]

Stoll, David. 1990. ¿América Latina se Vuelve Protestante? Las Políticas del Crecimiento Evangélico. Quito: Abya-Yala.

Tomasello, Michael. 2010. ¿Por Qué Cooperamos? Buenos Aires: Katz Editores.

Warneken, Felix, Karoline Lohse, Alicia P. Melis, and Michael Tomasello. 2011. Young children share the spoils after collaboration. Psychological Science 22: 267-73. [CrossRef]

Waugh, Whitney, Celia Brownell, and Brianna Pollock. 2015. Early socialization of prosocial behavior: Patterns in parents' encouragement of toddlers' helping in an everyday household task. Infant Behavior and Development 39: 1-10. [CrossRef]

Yazan, Bedrettin. 2015. Three Approaches to Case Study Methods in Education: Yin, Merriam, and Stake. The Qualitative Report 20: 134-52.

(C) 2019 by the authors. Licensee MDPI, Basel, Switzerland. This article is an open access article distributed under the terms and conditions of the Creative Commons Attribution (CC BY) license (http://creativecommons.org/licenses/by/4.0/). 